\title{
Nutritional Value of Date Fruits and Potential Use in Nutritional Bars for Athletes
}

\author{
Sulaiman Aljaloud', Heather L. Colleran², Salam A. Ibrahim² \\ ${ }^{1}$ College of Sport Sciences and Physical Activity, King Saud University, Riyadh, KSA \\ ${ }^{2}$ Food and Nutritional Sciences Program, College of Agriculture and Environmental Sciences, North Carolina A\&T State \\ University, Greensboro, NC, USA \\ Email: saljaloud@ksu.edu.sa
}

How to cite this paper: Aljaloud, S., Colleran, H.L. and Ibrahim, S.A. (2020) Nutritional Value of Date Fruits and Potential Use in Nutritional Bars for Athletes. Food and Nutrition Sciences, 11, 463-480. https://doi.org/10.4236/fns.2020.116034

Received: April 24, 2020

Accepted: June 13, 2020

Published: June 16, 2020

Copyright () 2020 by author(s) and Scientific Research Publishing Inc. This work is licensed under the Creative Commons Attribution International License (CC BY 4.0).

http://creativecommons.org/licenses/by/4.0/

\section{(c) (i) Open Access}

\begin{abstract}
The date palm (Phoenix dactylifera L.) is one of the oldest primary staple crops in Southwest Asia and North Africa. Date palms are also grown in Australia, Mexico, South America, Southern Africa, and the United States, especially in Southern California, Arizona, and Texas. Date fruit is a high nutritional value food that is rich in carbohydrates, dietary fibers, proteins, minerals and vitamin B complex such as thiamine (B1), riboflavin (B2), niacin (B3), pantothenic (B5), pyridoxine (B6), and folate (B9). Carbohydrates comprise $70 \%$ of date fruit mainly as fructose and glucose. Minerals in date fruits are calcium, iron, magnesium, selenium, copper, phosphorus, potassium, zinc, sulfur, cobalt, fluorine, and manganese. Date fruits are highly nourishing and may thus confer numerous potential health benefits. In recent years, a huge interest in the abundant health promoting properties of date fruits has led to the need to develop new food products using dates as a source of nutrients. Thus, the aim of this paper is to review the nutritional value of date fruits in the context of the potential use of dates in nutrition bars for athletes.
\end{abstract}

\section{Keywords}

Date Palm, Health Benefits, Nutritional Value, Athletes

\section{Introduction}

Athletes around the world depend on adequate nutrition for performance and endurance activities. Consequently, the need for energy balance and efficient body metabolism cannot be overemphasized. Such a diet should also be able to enhance the basal metabolism of athletes in their sporting endeavors. The quest for good nutrition is key for all and sundry, as it serves as a bedrock for the pro- 
vision of a balanced proportion of both macro- and micronutrients. Energy bars are nutritious snack foods that are enjoyed by most active individuals including athletes. Energy bars are also an excellent source of proteins, and natural sugars (carbohydrates) which are nutritionally balanced to enhance performance. In addition to energy provision, the protein content in energy bars also helps to build muscle mass and protects tissues.

Fruits from dates are a natural reservoir of sugars including sucrose, fructose and glucose which make up two-thirds of the total date flesh. One hundred grams of fresh dates contain approximately 157 calories of energy, whereas dry dates contain more than 300 calories of energy per 100 grams [1]. Apart from their high natural sugar content, dates also possess additional nutritive components in the form of proteins, crude fiber, fats, and antioxidants thus making dates a functional food with significant health benefits. Blending dates with other rich natural foods could therefore boost the energy performance and well-being of athletes and sports enthusiasts. In addition, dates supplemented with probiotics as an added ingredient would be a high energy food that would aide in the support the natural flora in the gastrointestinal tract. An energy bar formulation comprised of dates, probiotics and other high-end carbohydrate and protein sources could thus potentially boost the immune system of athletes and increase their energy balance during performance. The objective of this report, therefore, was to discuss the nutritional value of date fruits and present potential use of dates in nutritional bars for athletes.

\section{History and Origin of Dates}

The date palm is thought to be one of the oldest plants in the world with a 7000-year history. The planting of this fruit coincided with some of the oldest civilizations that extended from Northeast Africa to northwest of the Tigris and Euphrates plateau [2]. It is believed that the Phoenicians were among the first people to cultivate the date palm around the Mediterranean region in ancient times. The date palm name, Phoenix dactylifera originated with the Greeks when the fruit was transferred from the Phoenicia region to the Mediterranean region [2]. This date palm, has been considered to be one of the most important plants in the arid, desert area of the Middle East, Southern Asia and Northern Africa for over 5000 years [3]. The date palm fruit is also the major staple food and primary source of agricultural wealth in the United Arab Emirates (UAE) region [4].

The date palm ( $P$. dactylifera L.) belongs to the Arecaceae (or palmae) family and structurally consists of three main parts, namely: 1) flesh with thin crust, 2) date pit, and 3) cap as shown in Figure 1. This fruit has been planted for many years in the semi-arid and desert areas of the Middle East, Pakistan, India, in the Canary Islands, and in the northern African countries for fuel, shade, fiber, and as building material [5] [6]. The commercial production of dates in the USA, began in the late $19^{\text {th }}$ and early $20^{\text {th }}$ centuries and is still considered to be an important component of desert agriculture in Southern California and Arizona [3]. 

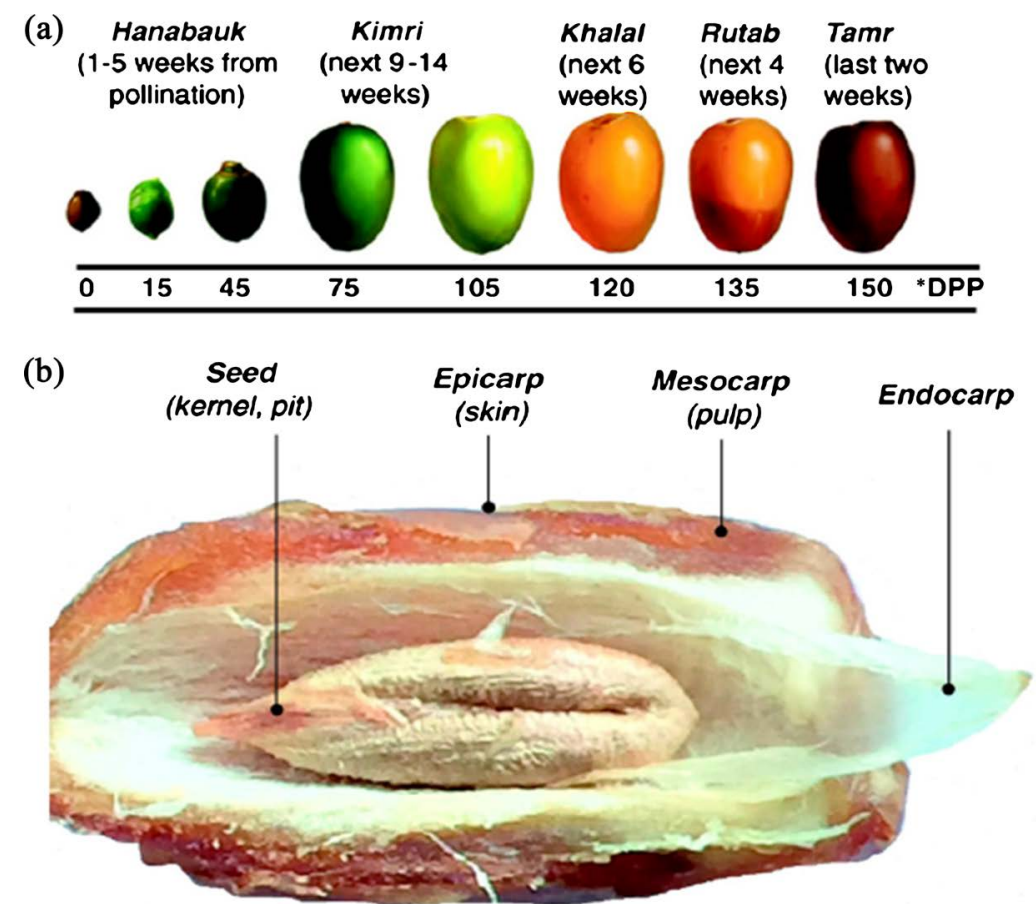

Figure 1. (a) The different fruiting stages of the date palm and (b) Anatomy of the date fruit (Adapted from [72]).

Date palm trees are very resistant to harsh climatic conditions and can withstand a vast range of temperatures (from $-6^{\circ} \mathrm{C}$ to $50^{\circ} \mathrm{C}$ ). They are also resistant to both water and soil salinity, and the most appropriate area for their growth is in arid regions with hot, dry climates and limited rainfall [7]. The total production of date fruits globally was more than 7.5 million tons in 2017 [8].

Five countries provide $54 \%$ of the total global production of date fruits globally include; Egypt (1.08 million tons), Iran (0.95 million tons), Saudi Arabia (1.08 million tons), Iraq (1.08 million tons) and the United Arab Emirates (UAE, 1.08 million tons), respectively [9]. Cultivation of the date palm in UAE has increased considerably in the last two decades with over 250 varieties being cultivated in various parts of the country, most notably in Al Ain and Abu Dhabi. The growth of date fruits in the UAE is paralleled by its high consumption rate, with the per capita daily intake being $10 \mathrm{~g}$ to $200 \mathrm{~g}$ in Abu Dhabi alone [10].

\subsection{Date Cultivars and Fruit Texture}

Globally, there are several thousand known date cultivars of commercial importance. Most of the top cultivars are grown extensively around the world and include the following four important commercial varieties: Deglet Noor, Zahidi, Khadrawy, and Halawy. Deglet Noor is the most popular cultivar and has the highest cultivation rate due to its large fruit size, light color, delicate flavor, and considerable shelf life during storage [7]. Regarding fruit texture, dates are categorized into three groups as soft (e.g. Barhi, Halawy, Khadrawi, and Medjhool), semi-dry (e.g. Dayri, Deglet Nour, and Zahidi), and dry (e.g. Thoory). The texture of dates largely depends on the amount of pectin methylation as the less the 
methylation amount, the softer the date becomes. The Tamer date is the softest (with 39\% methylation) whereas the Kimri date is the toughest (with $72 \%$ methylation) [1] [11] [12]. The moisture and fiber content are also expected to play a role in determining whether a date is soft, semi-dry or dry [13].

\subsection{Proximate and Nutritive Composition of Dates}

Date fruit is very sweet and comprise about $50 \%-88 \%$ of the total weight according to cultivar type, the ripening stage and the total water content. The date flesh is composed of sugars, primarily fructose and glucose. These sugars make up two-thirds of the total date flesh, with one-fifth of the total fleshy composition comprised of water and just a small remaining portion of dietary fiber. Other rich components of dates include its protein, fat, crude fiber, minerals, vitamins (especially vitamin B) and tannins among others [14] [15]. Dates possess very high nutritive value and can thus play an effective role in providing human nutritional needs. For example, 100 grams of fresh dates contain approximately 157 calories of energy, whereas dry dates contain more than 300 calories of energy per 100 grams [1]. Table 1 summarizes the general proximate composition of the date fruit.

The flesh of dates contains between $0.2 \%-0.5 \%$ oil compared to $7.7 \%-9.7 \%$ in the seed or pit. Date fruit contains unsaturated fatty acids which include palmitoleic, oleic, linoleic and linolenic acids. Date seeds could be used as a potential source of oleic acid as the oleic acid content of the seeds varies between $41.1 \%$ and $58.8 \%$. The protein content in dates contains twenty-three (23) different types of amino acids, some of which are non-existent in popular fruits such as oranges, apples and bananas. Date fruit contains at least six vitamins including a small amount of vitamin $\mathrm{C}$ plus vitamin $\mathrm{B}(1)$ thiamine, $\mathrm{B}(2)$ riboflavin, nicotinic acid (niacin) and vitamin $\mathrm{A}$. The pectin content which ranges between $0.5 \%-3.9 \%$ also confers health benefits such as lowering cholesterol levels. The essential nutrients in dates thus make this an ideal food, providing a wide array of beneficial nutrients for human health and development [16].

\subsection{Carbohydrates (Sugars)}

The major chemical constituents of dates are carbohydrates, which include reducing sugars such as glucose and fructose as well as non-reducing sugars such

Table 1. Proximate composition of dried date fruits.

\begin{tabular}{|c|c|c|c|c|c|c|c|c|c|c|}
\hline $\begin{array}{c}\text { Date } \\
\text { Variety }\end{array}$ & $\begin{array}{l}\text { Moisture } \\
(\mathrm{g} / 100 \mathrm{~g})\end{array}$ & $\begin{array}{l}\text { Protein } \\
(\mathrm{g} / 100 \mathrm{~g})\end{array}$ & $\begin{array}{l}\text { Lipid } \\
(\mathrm{g} / 100 \mathrm{~g})\end{array}$ & $\begin{array}{c}\text { Total Sugars } \\
(\mathrm{g} / 100 \mathrm{~g})\end{array}$ & $\begin{array}{c}\text { Ash } \\
(\mathrm{g} / 100 \mathrm{~g})\end{array}$ & $\begin{array}{c}\text { Calcium } \\
(\mathrm{mg} / 100 \mathrm{~g})\end{array}$ & $\begin{array}{l}\text { Potassium } \\
(\mathrm{mg} / 100 \mathrm{~g})\end{array}$ & $\begin{array}{l}\text { Sodium } \\
\text { (mg/100g) }\end{array}$ & $\begin{array}{c}\text { Magnesium } \\
(\mathrm{mg} / 100 \mathrm{~g})\end{array}$ & $\begin{array}{c}\text { Phosphorus } \\
\text { (mg/100g) }\end{array}$ \\
\hline Ajwa & 22.8 & 2.91 & 0.47 & 74.3 & 3.43 & 187 & 476.3 & 7.5 & 150 & 27 \\
\hline Medjool & 21.32 & 1.81 & 0.39 & 66.47 & 1.74 & 64 & 696 & 1 & 54 & 62 \\
\hline Deglet Noor & 13.50 & 1.71 & 0.40 & 86.42 & 1.78 & 25.05 & 774.71 & 5.79 & 50.26 & - \\
\hline Dabbas & 19.5 & 2.54 & 0.41 & - & 1.64 & 35.71 & 419.05 & 14.38 & 42.17 & 48.36 \\
\hline Barhi & 29.5 & 2.3 & 0.10 & - & 1.40 & 12 & 855 & 75 & 82 & - \\
\hline
\end{tabular}


as sucrose, and small amounts of polysaccharides such as cellulose and starch [16]. According to Shafiei et al., polysaccharides in the date flesh and seeds or pits contain xylose, arabinose, glucose, and galactose [17]. The level of sucrose is higher in dried dates than on soft dates. Soft dates, however, contain reducing sugars, except for a few cultivars that contain sucrose [18] [19]. It is interesting to note that semi-dry dates have nearly $50 \%$ each of sucrose and reducing sugars [20]. According to Eltayeb, et al., semi-dry dates contain more sucrose than reducing sugars [18].

However, the cultivar, Deglet Nour which grows mostly in California, contains only sucrose [21]. It has also been observed that dry dates with solid and dry flesh contain relatively more sucrose than reducing sugars [18]. In general, dates can be grouped into two types depending on the type of sugars contained in the dates. These are sucrose containing dates or reducing sugar containing dates [22]. The composition of sugars (sucrose, glucose and fructose) along with the glucose to fructose ratio $(\mathrm{G} / \mathrm{F})$ in some selected date fruit varieties in the UAE are summarized in Table 2. The moisture content of the date is indirectly proportional to its sugar content, such that dates with low moisture content always contain high sugar and vice versa. Date varieties in Saudi Arabia contain about $70 \%$ reducing sugars with almost equal quantities of both glucose and fructose [19]. The most important commercial characteristics of dates are based on the sugar content which is significant for both fresh consumption and for fruit processing [23].

Because dates contain a relatively high sugar content, they may also have an important agro-industrial future as a potential source of refined sugar [24] [25] [26] [27].

\subsection{Protein}

The protein content of dates ranges from $1 \%-7 \%$ and includes essential amino

Table 2. Sugar composition of selected date fruit varieties in UAE [4].

\begin{tabular}{ccccc}
\hline Date Variety & Sucrose $^{*}$ & Glucose $(\mathrm{G})^{*}$ & Fructose $(\mathrm{F})^{*}$ & G/F ratio \\
\hline Barhe & $4.2 \pm 0.1$ & $34.6 \pm 0.1$ & $39.3 \pm 0.2$ & 0.88 \\
Bumaan & $4.4 \pm 0.3$ & $32.3 \pm 0.1$ & $34.8 \pm 0.1$ & 0.93 \\
Dabbas & $6.4 \pm 0.7$ & $36.3 \pm 0.5$ & $35 \pm 0.2$ & 1.04 \\
Fard & $5.2 \pm 0.2$ & $31.3 \pm 0.2$ & $32.1 \pm 0.2$ & 0.98 \\
Jabri & $5.8 \pm 0.1$ & $35.2 \pm 0.2$ & $35.6 \pm 0.3$ & 0.99 \\
Khalas & $6.1 \pm 0.5$ & $33.4 \pm 0.3$ & $33.2 \pm 0.1$ & 1.01 \\
Lulu & $6.7 \pm 0.3$ & $40.2 \pm 0.5$ & $35.5 \pm 0.1$ & 1.13 \\
Maktoomi & $6.9 \pm 0.1$ & $47.4 \pm 0.4$ & $35.7 \pm 0.2$ & 1.33 \\
Raziz & $4.5 \pm 0.1$ & $31.8 \pm 0.7$ & $33.9 \pm 0.1$ & 0.94 \\
Shikat & $4.9 \pm 0.2$ & $35.1 \pm 0.4$ & $36.6 \pm 0.3$ & 0.96 \\
Shishi & $5.5 \pm 0.6$ & $33.7 \pm 0.2$ & $34.3 \pm 0.2$ & 0.98 \\
\hline
\end{tabular}

*Results are presented as $\mathrm{g} / 100 \mathrm{~g}$ of fruit flesh's weight. 
acids required for metabolic functioning of the human body [15]. According to Al-Shahib and Marshall, date proteins contain twenty-three (23) types of amino acids, some of which are not present in popular fruits such as oranges, apples and bananas. Most date cultivars contain the following amino acids: lysine, histidine, arginine, aspartic acid, threonine, glutamic acid, serine, proline, glycine, alanine, cystine, valine, methionine, isoleucine, leucine, tyrosine, and phenylalanine [16]. It is worthy to note that glutamic and aspartic acid make up the highest amino acid quantities in dates according to Nour and Magboul [26]. These proteins are rich in acidic amino acids and low in sulphur containing amino acids such as methionine and cysteine [27].

The molecular weight of date proteins varies from 12,000 - 72,000 daltons. Most date proteins are water soluble albumins. Dates grown in Middle Eastern countries such as Saudi Arabia, Jordan, Oman and Iran have very similar protein profiles and contain complex protein mixtures, whereas some varieties grown in the US have very low protein and a simple protein profile as well [27]. During date sugar production, the extracted juice becomes darkened as a result of proteins and thus must be removed [5].

\subsection{Fat}

Date fruit typically contains little fat, with most of the fat concentrated in the crust. The fat content in the flesh ranges between $0.1 \%-0.5 \%$, and fat plays an essential role in the protection of the fruit more than in the nutritional value of the date flesh [13] [16]. For example, eight fatty acids exist in very low concentration in the flesh. The major saturated fatty acids in dates include lauric, myristic, and palmitic acids, while the major unsaturated fatty acid is oleic acid [16]. Other fatty acids in minor quantities include capric, caprylic, stearic, margaric, arachidic, linoleic, and pelargonic [13] [16].

\subsection{Crude Fiber}

The daily consumption of $100 \mathrm{~g}$ of dates provides approximately $50 \%-100 \%$ of the recommended daily amount of fiber [16]. The insoluble part of the date flesh is its crude fiber which is comprised of cellulose, hemicellulose, lignin, and lignocellulose. The quantities of cellulose, hemicellulose, and lignin of date flesh are $1.55 \%, 1.28 \%$, and $2.01 \%$, respectively [5]. The crude fiber in high quality, ripe dates, amounts to $2 \%-6 \%$ of date flesh, whereas in low quality dates, this percentage can be as high as $10 \%$ with the fiber being used primarily for industrial purposes [13]. The crude fiber content of dates is, however, not a good indication of its total dietary fiber content since the fiber also contains pectin, hemicellulose, cellulose, gums, mucilages, starch, and lignin depending on its stage of maturity [28] [29]. According to Al-Farsi et al., the total dietary fiber content of dates varies from 6.26 to $8.44 \mathrm{~g} / 100 \mathrm{~g}$, of which $84 \%-94 \%$ is insoluble fiber [30]. However, based on other studies, dates contain between $6.4 \%-11.5 \%$ dietary fiber depending on the variety type and the stage of ripening [13] [16]. Date 
fruit also contains a special type of fiber known as $\beta$-D-glucan which have been confirmed to have high anticancer activity [30] [31]. These polysaccharides have a main chain of $(1 \rightarrow 3)$ - $\beta$-D-glucopyranosyl residues with $(1 \rightarrow 6)$-linked branched saccharide residues [31]. However, accurate information regarding the exact quantity of glucans in the date fruit is not available at present.

Date crude fiber plays an important role in date processing as it indirectly affects the yield in liquid date sugar production. The higher the crude fiber and moisture content, the less the yield during production of liquid date sugar [14]. During the production of date syrup and its storage, pectin causes gelation, which results in lower liquid sugar yields. However, this situation is eliminated by pre-treatment of the extracted juice with pectinase [5] [32]. According to research conducted by Elleuch et al., on the physiochemical properties of dietary fiber extracted from date flesh, dietary fiber concentrates exhibited functional properties such as high water-holding capacity, high oil-holding capacity, emulsifying, pseudoplasticity behavior of their suspensions, and gel formation that are important to the food industry [33]. Dietary fiber could also be used as an ingredient in many food products such as in dairy, soup, meat, bakery products and jam in order to modify their textural properties, avoid syneresis, and stabilize high fat food and emulsions.

\subsection{Minerals and Vitamins}

Dates are rich sources of vitamins and minerals and are known to provide a number of health benefits. For example, dates have been reported to have at least fifteen [15] different minerals such as magnesium, manganese, phosphorus, iron, calcium, potassium, sodium and zinc. The percentage of each mineral in dried dates varies between 0.1 to $916 \mathrm{mg} / 100 \mathrm{~g}$ of date flesh [5] [34] [35]. Dates also have high levels of copper, selenium, potassium and magnesium, average concentrations of manganese, iron, phosphorus, cobalt, fluorine, zinc and calcium, as well as small quantities of boron [5] [16]. In many date varieties, the potassium content in the flesh can be as high as $0.9 \%$, while some seeds could have as much as $0.5 \%$ [16]. Potassium is thus considered to be the predominant microelement in the date flesh, whereas the phosphorous content is less than that of the other macro-elements [27] [36].

The micro-elements zinc and copper are found in low concentrations in dates, and iron is present in higher concentrations [36]. The high potassium and low sodium content in dates are beneficial for people suffering from hypertension. Boron is very useful in the treatment of brain cancer and, in conjunction with other vitamins, is also used in the treatment of rheumatism [37]. The abundance of fluorine present in dates is useful for the prevention of tooth decay. Moreover, the selenium content of dates has beneficial effects for cancer prevention and strengthening of the human immune system [16] [38]. According to Al-Showiman et al., the amount of selenium is in the range of $1.48-2.96 \mu \mathrm{g} / \mathrm{g}$ in some date varieties [37]. Dates could be used as iron deficiency supplements without causing 
side effect such as nausea, headache, and anorexia that may occur with the use of conventional iron supplements.

Dates are a reasonable source of vitamins compared to other dried fruits [39]. In addition, fresh dates contain higher concentrations of vitamins than dried dates as a result of the depletion of vitamins during the drying process. Thiamin, riboflavin, niacin, ascorbic acid, pyridoxin, and vitamin A are six vitamins that have been confirmed to be present in dried dates in relatively low concentrations [16] [40].

\subsection{Antioxidants}

Dates contain an array of phytochemicals that are abundant in the fruit and are a rich source of antioxidants. Notably among these phytochemicals are carotenoids (beta-carotene, lycopene, lutein, zeaxanthin, and neoxanthin), the phenolics; the cinnamic acids and their derivatives (ferulic, sinnapic, syringic, vanillic, gallic, caffeic, protocatechuic, coumaric acids, and their derivatives such as dactilyferic acids, etc.), flavonoid glycosides (luteolin, methyl luteolin, quercetin, and methyl quercetin) flavones, flavonols (catechin, epicatechin), flavoxanthin, anthocyanins, and so on [13] [34] [41]. The concentration of these phytochemicals in dates, however, decreases with advancing stage of fruit maturity. The early stage of maturity is linked to astringency in the date fruit which is as a result of the level of tannins; however, this decreases with fruit ripening [5] [34]. The protein content of dates plays a critical role in the non-oxidative browning (maillard reactions) of dates and helps in the precipitation of tannins during the ripening process [5] [42].

Phenolic compounds and carotenoids (flavonoids and anthocyanins) can contribute to varying degrees of antioxidant and antimutagenic activity. For example, the contribution of total phenolics toward antioxidant activity in dates is greater than that of ascorbic acid [43]. Many research studies have confirmed the free radical scavenging properties of date fruit as well as date juice extracts Most of the antioxidants observed in dates have been reported to be hydrophilic or water soluble [34]. Some of the confirmed and reported data on the antioxidant activity of date fruit from different parts of the world such as Algeria [44], Kuwait [45], Iran [13], Bahrain [46], Oman [34], and the United States [47] has established the dual benefits of dates as providing an unparalleled source of natural antioxidants as well as being a good alternative for the improvement of flavor and color in food products due to their high content of active phenolic acids. [13] [33] [46] [48].

\section{Date Processing}

Dates contain a plethora of nutritive elements that are highly medicinal making dates a suitable product in many food applications. Dates are consumed either in their fresh or dried state, however, value addition through processing of the date fruit leads to an array of high end assorted products such as date juice concen- 
trates (spread, syrup and liquid sugar), fermented date products (wine, alcohol, vinegar, and organic acids) as well as date pastes for specialized and different uses in industries such as the bakery and confectionary sector [49].

Date processors have established their reputations by manufacturing products such as date paste, date syrup, honey, jam and vinegar that meet consumer acceptability standards. Date pectin, dietary fiber and syrup serve as food thickeners or gelling agents in processed foods such as confectionary products, jams, table jellies, soft cheeses and yogurt among others. Due to the vast benefits associated with value addition to this very special fruit, many studies have been extensively conducted on date juice extraction and date syrup processing [40] [50].

According to Ahmed et al., the general process includes steaming the dates, de-pitting, and macerating which transforms dates into a semi-solid form known as paste with an approximately $20 \%-23 \%$ moisture content and a water activity below 0.6 [51]. Date paste has thus become a sugar substitute in many food product formulations, and many confectioneries utilize it as an ingredient [52]. In the date syrup industry however, date processing involves mixing the fruit with water and applying heat at a temperature of $50^{\circ} \mathrm{C}$ for an hour. The liquid extract which primarily contains sugars is then filtered and concentrated in order to achieve the finished product. This process could be easily performed at home and in village settings by simple boiling and extraction of date juice. Date syrup processing can therefore be achieved on a small to medium scale or in a fully industrialized context [53]. It is also worthy to note that mature date fruit could also be processed into date bars [54].

\subsection{Date Bars as a Potential in Sports Nutrition}

Energy bars can be classified as dietary supplements that are often consumed by athletes and other physically active people to maintain their calorie needs. These bars provide the strength and vitality for sustained physical and mental activity and are typically high in carbohydrates and moderate in protein content [55]. Energy bars are globally known to be a convenient ready-to-eat food which does not require any preparation and can be easily stored at room temperature. These bars are uniquely made to fit a specific purpose and are consumed by all age groups in order to enhance daily energy values. Energy bars come in various sizes and shapes, and they are a nutritiously dense alternative to food. In addition, energy bars are uniquely aligned to various objectives or diets (i.e. low carb, organic, kosher, etc.) and exercise needs (i.e. pre-workout, during workout or post-workout) [56]. Moreover, they have a balanced nutritional profile meeting both macro and micronutrients requirements for enhanced body metabolism [57]. Fruit based bars can serve the purpose of an energy bar as they are an exceptional source of superior nutritive and bioactive elements that provide energy required to meet the recommended daily nutritional intake [58].

Date fruit is a good source of carbohydrates in the form of sugars that constitute about $78 \%$ of the whole fruit. This reservoir of natural sugars is readily pro- 
vided to the human body as a source of energy [42]. Date fruit consumption also provides consumers with therapeutic benefits and nutrition that are vital for the proper functioning of the human body. The fruit is either consumed directly (fresh or in dried form) or is converted into products such as date paste and syrup, among others [59]. According to Tang et al., date fruit provides inherent antioxidant, anti-inflammatory, gastrointestinal-protection, and anticancer properties that are vital for human health [59]. In addition, these properties may help reduce and control diabetes mellitus and other cardio-and cerebrovascular diseases (CCVD) [59]. Fruit bars are a better alternative to direct consumption of dates, as fruit bars are especially geared towards energy provision for active individuals [58]. It is important for athletes to consider natural food sources that provide a canister of energy at any point in time in order to replenish their strength after strenuous activities.

An excellent food source that contains appropriate amounts of both macroand micronutrients is therefore essential in order to provide for the energy and nutrition needs of athletes, sportspeople, and others with active lifestyles. Date bars could fulfil this requirement under sports nutrition, as such bars may enhance athletic performance by reducing fatigue and the risk of disease and injury as well as enable athletes to optimize training and recover faster [60]. The centrepiece goal of virtually all athletes is to balance energy intake with energy expenditure in order to prevent an energy deficit or an excess of it [61].

\subsection{Use of Dates in Nutritional Bars for Athletes}

Dates are naturally sweet due to their high content of sugars such as sucrose, glucose and fructose. These sugars provide a cannister of energy when used as a complementary ingredient in nutritional bars for athletes. Date fruits are medicinal and are classified as functional foods due to their rich source of sugars, antioxidants, vitamins, minerals and other major macronutrients. The texture of dates facilitates easy blending with other cereals or ingredients in food product development which ensures solid attachment and holds the matrix together firmly [5]. The bioavailability of nutrients in dates thus ensures a complete healthy food for consumers of all ages. Dates contain high antioxidant and antimutagenic properties that can help protect athletes and also prevent fatigue and illness associated with poor recovery [45]. The fundamental components of an athlete's performance are the right nutrition and eating habits. Nutritional bars can provide this benefit for athletes partaking in endurance, all day tournaments or competitions and intense work out sessions.

The production of energy for prolonged or intense activity depends on proper nutrition. The consumption of carbohydrates before and during exercise provides an exogenous fuel source for the muscles and the central nervous system [62]. Human metabolism primarily depends on carbohydrate and fats oxidation which is vital for the proper functioning of cells and tissues. Moreover, energy balance is an important aspect in the performance of an athlete during both high 
and low intensity activities. The nutritional requirements of an athlete are based on the intensity of exercise or workout and should balance the total energy production in order to compensate for the expended energy [62].

\subsection{Probiotic Nutritional Bar for Athletes}

The word, probiotics, was derived from the Greek words "for life" and has had many definitions over the years [63]. Huis Int Veld and Havenaar broadened the definition of probiotics as being "a mono- or mixed culture" of live microorganisms which, when consumed by man or animal (e.g. as dried cells or as a fermented product), beneficially affect the host by improving the properties of the indigenous microflora [64]. According to the Food and Agricultural Organisation (FAO)/World Health Organisation [65], probiotics are defined as "live microorganisms, which, when administered in adequate amounts, confer a health benefit on the host." Additionally, according to the International Olympic Committee (IOC), "Probiotics are defined as live micro-organisms that, when administered orally for several weeks, can increase the number of beneficial bacteria in the gut. Probiotics have been associated with a range of potential benefits to gut health as well as modulation of immune function" [66].

Strenuous, extensive exercise induces stress on the gastrointestinal (GI) tract that increases the probability of multiple symptoms linked to a disturbed gut microbiota and a decrease in performance [67]. These symptoms include abdominal cramps, acid reflux, nausea, vomiting, diarrhea, and permeability of the gut that may lead to systemic endotoxemia [68]. Consumption of date bars fortified with probiotic bacteria will ultimately provide a dual benefit to the athlete by releasing enough calories for performance and holistically protecting the athlete's gastrointestinal tract effectively. The immune system readily and heavily protects the GI tract, as the GI tract is the major pathway for pathogen entry. Consequently, a boost in the immune system to heighten its defenses against pathogens in the GI tract is the sole objective and potential benefit of probiotics for athletes [67]. Date fruit nutritional bars as a vehicle for probiotic bacteria will effectively provide athletes with a stronger immune system via healthy gut bacteria.

Probiotics will thus serve as a functional modulator of the microbiome in athletes and will potentially enhance health, exercise adaptation and performance. A healthy, enriched and well protected microbiome may also impart an indirect functional influence on various indices of exercise performance and recovery in athletes [69].

\subsection{Date Nutritional Bar for Athletics}

Our research team in the food microbiology laboratory developed a new nutritional bar that supports the health of athletes. The bar consisted of pitted soft dates, gluten free rolled oats, protein powder, probiotic mix, chokeberry powder, palatinose and other additives such as chocolate, milk, vanilla, salt and maple sy- 
rup. The standard recipe for the nutritional bar was derived after series of test trials to attain the best product formulation.

The steps involved in the development of this novel product included processing the oats in a food processor fitted with a steel blade and till finely ground into a flour. The protein powder mixture, pitted dates, maple syrup (optional), vanilla, salt, milk and (optional) melted unsweetened chocolate were all added afterwards. The mixture was then processed until all ingredients were well-combined and tacky (but not sticky) to the touch. More milk, probiotic mixture, palatinose and chokeberry powder was added and further processed till the mixture reached the appropriate and expected consistency.

In the event of not using the melted unsweetened chocolate, more milk, will have to be added which will result in the bars not holding together as firmly when shaped. The mixture was transferred to the prepared pan and firmly pressed into an even layer, with the top being smoothed as much as possible. The pan was then covered with parchment paper and placed in the refrigerator or the freezer to chill until firm (about 1 hour in the refrigerator, or 20 minutes in the freezer). The bars were removed from the pan and sliced into 10 or 12 equal-sized rectangular bars. The rectangular bars were then dipped in the optional melted bittersweet chocolate to coat and allowed to sit at room temperature until set. The bars were stored in a sealed container in the refrigerator and were readily available to be consumed. The formulated date bar is as shown in Figure 2.

\section{Conclusion}

Dates have been underutilized in food product development, especially in energy bars, although they are highly nutritious and contain an array of natural sugars that could enhance athletic performance by providing energy. In addition, the

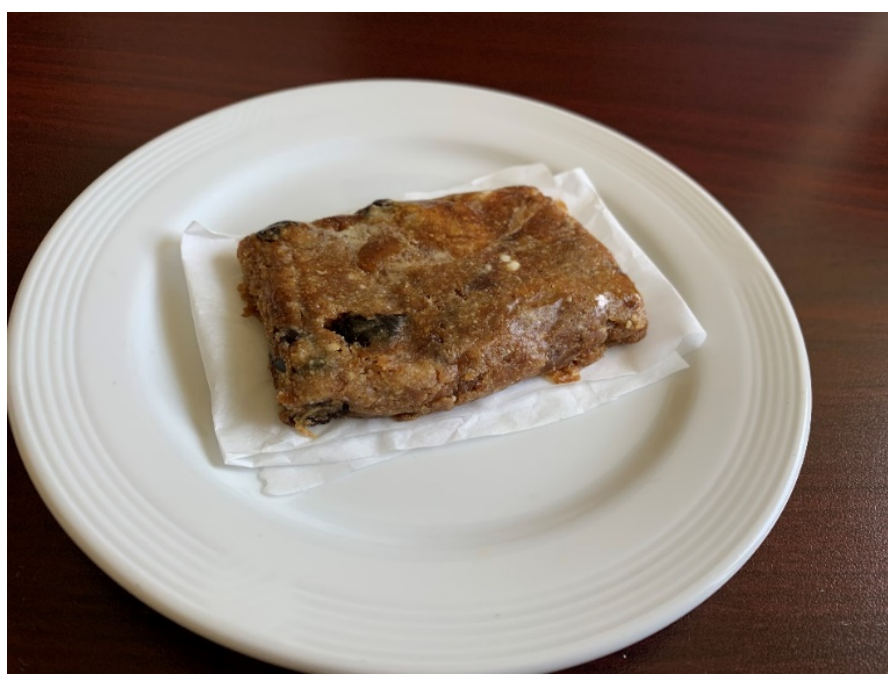

${ }^{\star}$ Original source is Food Preparation and Meal Management Laboratory at North Carolina A\&T State University.

Figure 2. Formulated date nutritional bar for athletes. 
synergistic property of dates with other complementary ingredients such as cereals and other high protein food sources could be a new potential in nutritional bar formulations with the objective of providing a complete energy and nutritious, food for athletes and active individuals. Few studies [70] [71] performed with probiotic bacteria with dates as a medium superimpose that, its high natural sugars provide an ambient environment for it to effectively thrive. Probiotic bacteria incorporated in the formulated date bar product, will therefore provide beneficial support to the gastrointestinal guts of athletes. The addition of probiotic bacteria to dates in the formulation of nutritional or energy bars will also support the needed energy levels of athletes and active individuals. Research has confirmed the impact of probiotic bacteria on the health of athletes; hence its application in date nutritional bars will go a long way to address energy deficits before, during and after high and low intensity activities. We formulated a probiotic date nutritional bar for athletes and found that dates in conjunction with probiotic bacteria could serve as a highly sought-after nutritional energy bar for the purpose of athletic performance and endurance. However, with further research, dates energy bars could always serve as a super healthy functional food for athletes and individuals with various objectives of exercising and staying healthy and active.

\section{Acknowledgements}

The authors extend their appreciation to the International Scientific Partnership Program ISPP at King Saud University for funding this research work through ISPP-153. This publication was made possible by grant number NC.X-267-512-170-1 from the National Institute of Food and Agriculture (NIFA) and the Department of Family and Consumer Sciences and the Agriculture Research Station at North Carolina Agriculture and Technical State University (Greensboro, NC, USA).

\section{Conflicts of Interest}

The authors declare no conflicts of interest regarding the publication of this paper.

\section{References}

[1] Rohani, A. (1988) Date Palm. Tehran University Publication Center, Tehran, Iran, 292.

[2] Dawson, W.H.W. (1982) Production and Preservation of Date. Translated by R. Sanadgol, Agricultural Promotion Organization Publication, Tehran, Iran, 326.

[3] Hodel, D.R. and Pittenger, D.R. (2003) Studies on the Establishment of Date Palm (Phoenix dactylifera "Deglet Noor") Offshoots. Part I. Observations on Root Development and Leaf Growth. Palms, 47, 191-200.

[4] Oladipupo Kareem, M., Edathil, A.A., Rambabu, K., Bharath, G., Banat, F., Nirmala, G.S. and Sathiyanarayanan, K. (2019) Extraction, Characterization and Optimization of High-Quality Bio-Oil Derived from Waste Date Seeds. Chemical Engineer- 
ing Communications, 1-11. https://doi.org/10.1080/00986445.2019.1650034

[5] Barreveld, W.H. (1993) Date Palm Products. FAO Agricultural Services Bulletin, No. 101.

[6] Nixon, R.W. (1951) The Date Palm- "Tree of Life" in the Subtropical Deserts. Economic Botany, 5, 274-301. https://doi.org/10.1007/BF02985151

[7] Hui, Y.H. (2006) Handbook of Fruit and Fruit Processing. Blackwell Publishing, Ames, Iowa, 391-411. https://doi.org/10.1002/9780470277737

[8] Mohd Jaih, A.A., Rahman, R.A., Razis, A.F., Ariffin, A.A., Al-Awaadh, A.A. and Suleiman, N. (2019) Fatty Acid, Triacylglycerol Composition and Antioxidant Properties of Date Seed Oil. International Food Research Journal, 26, 512-527.

[9] Food and Agricultural Organization (FAO) (2017) FAO Report. http://www.fao.org/faostat/en/\#rankings/countries_by_commodity

[10] Habib, H.M. and Ibrahim, W.H. (2011) Nutritional Quality of 18 Date Fruit Varieties. International Journal of Food Sciences and Nutrition, 62, 544-551. https://doi.org/10.3109/09637486.2011.558073

[11] Myhara, R.M., Al-Alawi, A., Karkalas, J. and Taylor, M.S. (2000) Sensory and Textural Changes in Maturing Omani Dates. Journal of the Science of Food and Agriculture, 80, 2181-2185. https://doi.org/10.1002/1097-0010(200012)80:15<2181::AID-JSFA765>3.0.CO;2-C

[12] Sawaya, W.N., Khalil, J.K. and Safi, W.J. (1984) Chemical Composition and Nutritional Quality of Date Seeds. Journal of Food Science, 49, 617-619. https://doi.org/10.1111/j.1365-2621.1984.tb12482.x

[13] Biglari, F., AlKarkhi, A.F.M. and Easa, A.M. (2008) Antioxidant Activity and Phenolic Content of Various Date Palm (Phoenix dactylifera) Fruits from Iran. Food Chemistry, 107, 1636-1641. https://doi.org/10.1016/j.foodchem.2007.10.033

[14] Hashempoor, M. (1999) Date Treasure. Agricultural Education Publication, Tehran, Iran, 668.

[15] Sablani, S.S., Shrestha, A.K. and Bhandari, B.R. (2008) A New Method of Producing Date Powder Granules: Physicochemical Characteristics of Powder. Journal of Food Engineering, 87, 416-421. https://doi.org/10.1016/j.jfoodeng.2007.12.024

[16] Al-Shahib, W. and Marshall, R.J. (2003) The Fruit of the Date Palm: Its Possible Use as the Best Food for the Future? International Journal of Food Sciences and Nutrition, 54, 247-259. https://doi.org/10.1080/09637480120091982

[17] Shafiei, M., Karimi, K. and Taherzadeh, M.J. (2010) Palm Date Fibers: Analysis and Enzymatic Hydrolysis. International Journal of Molecular Sciences, 11, 4285-4296. https://doi.org/10.3390/ijms11114285

[18] Eltayeb, E.A., Al-Hasni, A.S. and Farooq, S.A. (1999) Changes in Soluble Sugar Content during the Development of Fruits in Some Varieties of Omani Date Palm (Phoenix dactylifera L.). Pakistan Journal of Biological Sciences, 2, 255-258. https://doi.org/10.3923/pjbs.1999.255.258

[19] Tafti, A.G. and Fooladi, M.H. (2006) A Study on the Physico-Chemical Properties of Iranian Shamsaei Date at Different Stages of Maturity. World Journal of Dairy \& Food Sciences, 1, 28-32.

[20] Morton, J.F. (1987) Fruits of Warm Climates. Florida Flair Books, Miami, USA, 9.

[21] Ensminger, A.H., Ensminger, M.E., Konlande, J.E. and Robson, J.R.K. (1995) The Concise Encyclopedia of Foods and Nutrition. CRC Press LLC, Boca Raton, FL, 247. https://doi.org/10.1201/9781420048186

[22] Sawaya, W.N., Khalil, J.K., Safi, W.N. and Al-Shalhat, A. (1983) Physical and 
Chemical Characterization of the Saudi Date Cultivars at Various Stages of Development. Canadian Institute of Food Science and Technology Journal, 16, 87-92. https://doi.org/10.1016/S0315-5463(83)72065-1

[23] Fadel, M.A. (2008) Sugar Content Estimation of Date (Phoenix dactylifera, L.) Fruits in Tamr Stage. Agricultural Engineering International: The CIGR Ejournal

[24] Samarawira, I. (1983) Date Palm, Potential Source for Refined Sugar. Economic Botany, 37, 181-186. https://doi.org/10.1007/BF02858783

[25] Bacha, M.A., Nasr, T.A. and Shaheen, M.A. (1987) Changes in Physical and Chemical Characteristics of the Fruits of Four Date Palm Cultivars. Proc. Saudi Biol. Soc., 10, 285-295.

[26] Nour, A.A.M. and Magboul, B.I. (1985) Amino Acid Composition of Some Sudanese Date Cultivars. The Date Palm Journal, 4, 51-54.

[27] Ahmed, I.S.A., Al-Gharibi, K.N., Daar, A.S. and Kabir, S. (1995) The Composition and Properties of Date Proteins. Food Chemistry, 53, 441-446. https://doi.org/10.1016/0308-8146(95)99840-V

[28] Yousif, A.K., Benjamin, N.D., Kado, A., Alddin, S.M. and Ali, S.M. (1982) Chemical Composition of Four Iraqi Date Cultivars. The Date Palm Journal, 1, 285-294.

[29] Al-Farsi, M., Morris, A. and Baron, M. (2007) Functional Properties of Omani Dates (Phoenix dactylifera L.). Acta Horticulturae, 736, 479-488. https://doi.org/10.17660/ActaHortic.2007.736.46

[30] Ishurd, O., Sun, C., Xiao, P., Ashour, A. and Pan, Y. (2002) A Neutral $\beta$-D-Glucan from Dates of the Date Palm, Phoenix dactylifera L. Carbohydrate Research, 337, 1325-1328. https://doi.org/10.1016/S0008-6215(02)00138-6

[31] Ishurd, O. and Kennedy, J.F. (2005) The Anti-Cancer Activity of Polysaccharide Prepared from Libyan Dates (Phoenix dactylifera L.). Carbohydrate Polymers, 59, 531-535. https://doi.org/10.1016/j.carbpol.2004.11.004

[32] Fallahi, M. (1996) Growth, Treatment, and Packaging of Date. Barsava Publication, Tehran, Iran, 124.

[33] Elleuch, M., Besbes, S., Roiseux, O., Blecker, C., Deroanne, C., Drira, N. and Attia, H. (2008) Date Flesh: Chemical Composition and Characteristics of the Dietary Fibre. Food Chemistry, 111, 676-682. https://doi.org/10.1016/j.foodchem.2008.04.036

[34] Al-Farsi, M., Alasalvar, C., Morris, A., Baron, M. and Shahidi, F. (2005) Compositional and Sensory Characteristics of Three Native Sundried Date (Phoenix dactylifera L.) Varieties Grown in Oman. Journal of Agriculture and Food Chemistry, 53, 7586-7591. https://doi.org/10.1021/jf050578y

[35] Khan, M., Sarwar, A., Wahab, M. and Haleem, R. (2008) Physio-Chemical Characterization of Date Varieties Using Multivariate Analysis. Journal of Food Agriculture, 88, 1051-1059. https://doi.org/10.1002/jsfa.3187

[36] Gasim, A.A.A. (1994) Changes in Sugar Quality and Mineral Elements during Fruit Development in Five Date Palm Cultivars in Al-Madinah Al-Munawwarah. Journal of King Abdulaziz University, 6, 29-36. https://doi.org/10.4197/Sci.6-1.3

[37] Al-Showiman, S.S. (1998) Al Tamr, Ghetha Was Saha (Date, Food and Health). Dar Al-Khareji Press, Qassim, Saudi Arabia.

[38] Messaitfa, A. (2008) Fluoride Contents in Ground Waters and the Main Consumed Foods (Dates and Tea) in Southern Algeria Region. Environmental Geology, 55, 377-383. https://doi.org/10.1007/s00254-007-0983-4

[39] USDA National Database for Standard Reference (2011) United States Development of Agriculture. https://www.nal.usda.gov/fnic/usda-nutrient-data-laboratory 
[40] Al-Hooti, S., Sidhu, J.S. and Qabazard, H. (1995) Studies on the Physico-Chemical Characteristics of Date Fruits of Five UAE Cultivars at Different Stages of Maturity. Arab Gulf Journal of Scientific Research, 13, 553-569.

[41] Shahidi, F. and Naczk, M. (2004) Phenolics in Foods and Nutraceuticals. CRC Press, Boca Raton, FL. https://doi.org/10.1201/9780203508732

[42] Makki, M., Hamooda, A. and Al-Abri, A. (1998) The Date Palm, Culture, Operation and Maintenance. Modern Color Publishers, Muscat, Oman.

[43] Shivashankara, K.S., Isobes, S., Al-Haq, M.I., Takenaka, M. and Shinha, T. (2004) Fruit Antioxidant Activity, Ascorbic Acid, Total Phenol, Quercetin, and Carotene of Irwin Mango Fruits Stored at Low Temperature after High Electric Field Treatment. Journal of Agriculture and Food Chemistry, 52, 1281-1286. https://doi.org/10.1021/jf0302431

[44] Mansouri, A., Embarek, G., Kokkalou, E. and Kefalas, P. (2005) Phenolic Profile and Antioxidant Activity of the Algerian Ripe Date Palm Fruit (Phoenix dactylifera). Food Chemistry, 89, 411-420. https://doi.org/10.1016/j.foodchem.2004.02.051

[45] Vayalil, P.K. (2002) Antioxidant and Antimutagenic Properties of Aqueous Extract of Date Fruit (Phoenix dactylifera L. Arecaceae). Journal of Agriculture and Food Chemistry, 50, 610-617. https://doi.org/10.1021/jf010716t

[46] Allaith, A.A.A. (2008) Antioxidant Activity of Bahraini Date Palm (Phoenix dactylifera L.) Fruit of Various Cultivars. International Journal of Food Science and Technology, 43, 1033-1040. https://doi.org/10.1111/j.1365-2621.2007.01558.x

[47] Vinson, J.A., Zubik, L., Bose, P., Samman, N. and Proch, J. (2005) Dried Fruits: Excellent in Vitro and in Vivo Antioxidants. Journal of the American College of $\mathrm{Nu}$ trition, 24, 44-50. https://doi.org/10.1080/07315724.2005.10719442

[48] Al-Farsi, M. and Lee, C.Y. (2008) Nutritional and Functional Properties of Dates: A Review. Critical Review in Food Science and Nutrition, 48, 877-884. https://doi.org/10.1080/10408390701724264

[49] Chandrasekaran, M. and Bahkali, A.H. (2013) Valorization of Date Palm (Phoenix dactylifera) Fruit Processing By-Products and Wastes Using Bioprocess Technology-Review. Saudi Journal of Biological Sciences, 20, 105-120. https://doi.org/10.1016/j.sjbs.2012.12.004

[50] EI-Shaarawy, M., Mesallam, M.I., EI-Nakhal, A.S. and Wahdan, A.N. (1989) Studies on Extraction of Dates. Proceedings of the Second Symposium on Date Palm, AI-Hassa, Saudi Arabia, 3-6 March, 259-271.

[51] Ahmed, J., Ramaswamy, H.S. and Khan, A.R. (2005) Effect of Water Activity on Glass Transitions of Date Paste. Journal of Food Engineering, 66, 253-258. https://doi.org/10.1016/j.jfoodeng.2004.03.015

[52] Alhamdan, A.M., Hassan, B.H. (1999) Water Sorption Isotherms of Date Pastes as Influenced by Date Cultivar and Storage Temperature. Journal of Food Engineering, 39, 301-306. https://doi.org/10.1016/S0260-8774(98)00170-8

[53] FAO (1992) Food and Agriculture Organization of the United Nation. Rome, Italy, 391.

[54] Abd El-Mohsen, M. and Nezam El-Din, M. (1995) Technological Study on Dibis Production from the Siwi Date. Egyptian Journal of Food Science, 23, 229-239.

[55] Maheswari Alla, G.U. and Jithendran, L. (2018) Development and Analysis of Nutri Bar Enriched with Zinc for Sports Athletes. International Journal of Advanced Research in Science, Engineering and Technology, 5, 5558-5570.

[56] Clark, N. (2006) Energy Bars-Costly but Convenient. Palaestra, 22, 44. 
[57] Ryland, D., Vaisey-Genser, M., Arntfield, S.D. and Malcolmson, L.J. (2010) Development of a Nutritious Acceptable Snack Bar Using Micronized Flaked Lentils. Food Research International, 43, 642-649. https://doi.org/10.1016/j.foodres.2009.07.032

[58] Parn, O.J., Bhat, R., Yeoh, T.K. and Al-Hassan, A.A. (2015) Development of Novel Fruit Bars by Utilizing Date Paste. Food Bioscience, 9, 20-27. https://doi.org/10.1016/j.fbio.2014.11.002

[59] Tang, Z.X., Shi, L.E. and Aleid, S.M. (2013) Date Fruit: Chemical Composition, Nutritional and Medicinal Values, Products. Journal of the Science of Food and Agriculture, 93, 2351-2361. https://doi.org/10.1002/jsfa.6154

[60] Hoch, A.Z., Goossen, K. and Kretschmer, T. (2008) Nutritional Requirements of the Child and Teenage Athlete. Physical Medicine and Rehabilitation Clinics of North America, 19, 373-398. https://doi.org/10.1016/j.pmr.2007.12.001

[61] Meyer, F., O'Connor, H and Shirreffs, S.M. (2007) International Association of Athletics Federations Nutrition for the Young Athlete. Journal of Sports Sciences, 25, S73-S82. https://doi.org/10.1080/02640410701607338

[62] Burke, L.M., Hawley, J.A., Wong, S.H.S. and Jeukendrup, A.E. (2011) Carbohydrates for Training and Competition. Journal of Sports Sciences, 29, S17-S27. https://doi.org/10.1080/02640414.2011.585473

[63] Fuller, R. (1989) Probiotics in Man and Animals. Journal of Applied Bacteriology, 66, 365-378. https://doi.org/10.1111/j.1365-2672.1989.tb05105.x

[64] Huisint, V.J. and Havenaar, R. (1991) Probiotics in Man and Animal. Journal of Chemical Technology and Biotechnology, 51, 562-567.

[65] FAO/WHO (2002) Guidelines for the Evaluation of Probiotics in Food. Report of a Joint FAO/WHO Working Group on Drafting Guidelines for the Evaluation of Probiotics in Food, London Ontario, Canada, April 30 and May 1, 2002. Food and Agriculture Organization of the United Nations (FAO), Rome, Italy; World Health Organization (WHO), Geneva, Switzerland.

[66] Maughan, R.J., Burke, L.M., Dvorak, J., Larson-Meyer, D. E., Peeling, P., Phillips, S. M., Rawson, E. S., Walsh, N. P., Garthe, I., Geyer, H., et al. (2018) IOC Consensus Statement: Dietary Supplements and the High-Performance Athlete. British Journal of Sports Medicine, 52, 439-455. https://doi.org/10.1136/bjsports-2018-099027

[67] Rawson, E.S., Miles, M.P. and Larson-Meyer, D.E. (2018) Dietary Supplements for Health, Adaptation, and Recovery in Athletes. International Journal of Sport Nutrition and Exercise Metabolism, 28, 188-199. https://doi.org/10.1123/ijsnem.2017-0340

[68] De Oliveira, E.P., Burini, R.C. and Jeukendrup, A. (2014) Gastrointestinal Complaints during Exercise: Prevalence, Etiology, and Nutritional Recommendations. Sports Medicine, 44, 79-85. https://doi.org/10.1007/s40279-014-0153-2

[69] Salarkia, N., Ghadamli, L., Zaeri, F. and Sabaghian Rad, L. (2013) Effects of Probiotic Yogurt on Performance, Respiratory and Digestive Systems of Young Adult Female Endurance Swimmers: A Randomized Controlled Trial. Medical Journal of the Islamic Republic of Iran, 27, 141-146.

[70] Ayad, A., El-Rab, D., Shahbazi, A., Worku, M., Schimmel, K., Ejimakor, G., Zimmerman, T. and Ibrahim, S.A. (2016) Using Date Palm (Phoenix dactylifera L.) By-Products to Cultivate Lactobacillus reuteri spp. Journal of Food Research, 5, 77-81. https://doi.org/10.5539/jfr.v5n5p77

[71] Mjalli, A., Issa, A., Ibrahim, S.A., Rusch, L.M. and Abuzuaiter, A. (2019). Date Palm 
Medium Compositions and Methods. US Patent, US 20190316080A1.

[72] Ghnimi, S., Umer, S., Karim, A. and Kamal-Eldin, A. (2017) Date Fruit (Phoenix dactylifera L.): An Underutilized Food Seeking Industrial Valorization. NFS Journal, 6, 1-10. https://doi.org/10.1016/j.nfs.2016.12.001 